\title{
H.W. Longfellow: A Poetical-Dwelling Poet of Ecological Wisdom from the Perspective of Eco-criticism
}

\author{
Jingcheng $\mathrm{Xu}$ (Corresponding author) \\ Postgraduate, The School of Foreign Languages, Being Forestry University \\ Haidian District, Beijing 100083, China \\ E-mail: xjc396@126.com \\ Meifang Nangong \\ Associate Professor, The School of Foreign Languages, Being Forestry University \\ Haidian District, Beijing 100083, China \\ E-mail: mf.nangong@gmail.com
}

[Fund project] This is the stage achievement of the 2011 planning fund project for the research of humanities and social sciences supported by the Fundamental Research Funds for the Central Universities (Project Approval Number: RW2011-32)

Received: February 1, 2012

Accepted: February 23, 2012

Published: May 1, 2012

doi:10.5539/elt.v5n5p85

URL: http://dx.doi.org/10.5539/elt.v5n5p85

\begin{abstract}
Among a minority of Longfellow's studies in China and abroad, there has even scarcely been one made from the perspective of eco-criticism. Eco-criticism aims at exploring the relation between literature and natural environment to find out the ecological wisdom in literary works so as to awaken the ecological consciousness of the contemporaries. Henry Wadsworth Longfellow, a poet concerning much about nature, in his nature poems, shows the value of nature by evoking people's love and care for nature, and makes them reconsider the Man-Nature relationship so as to seek the ecological balance on earth, including that from within the human world. By reading Longfellow in the light of certain eco-ethical ideas, it is not difficult to discover the legacy glittering with ecological wisdom in his poetry. Such wisdom is highly connected with Longfellow's "environmental niche". Nowadays, with the increasing deterioration of the environment, the ecological wisdom implied in Longfellow's poetry is of tremendous significance.
\end{abstract}

Keywords: Eco-criticism, Henry Wadsworth Longfellow, Poetical-dwelling, Environmental niche

\section{Introduction}

\subsection{A Brief Introduction to H.W. Longfellow}

Life is real-Life is earnestAnd the grave is not its goal;

Not enjoyment, and not sorrow, Is our destined end or way;

But to act, that each to-morrow Find us farther than to-day.

In the world's broad field of battle, In the bivouac of Life,

Be not like dumb, driven cattle!

Be a hero in the strife!

Lives of great men all remind us 
We can make our lives sublime,

And, departing, leave behind us

Footprints on the sands of time;

Let us, then, be up and doing,

With a heart for any fate;

Still achieving, still pursuing,

Learn to labor and to wait.

The excerpt above, taken from Henry Wadsworth Longfellow's poem A Psalm of Life, is probably best embodied by what Longfellow fulfilled in his life.

Henry Wadsworth Longfellow (1807-1882), a famous American poet, was born to a lawyer family in Portland, Maine, United States. Quite rich as he was, he strived to study hard and fulfill his dream to be admitted to Bowdoin College at the age of 15 , in the fall of 1822 . Pursuing his literary goals by submitting poetry and prose to various newspapers and magazines, between January 1824 and his graduation in 1825, he had published nearly 40 minor poems. When he graduated from Bowdoin, he was ranked fourth in the class, and had been elected to Phi Beta Kappa, and gave the student commencement address. Like other writers and poets such as Nathaniel Hawthorne, and Edgar Allen Poe in his time, life seemed to play jokes with him. He had experienced two tragedies in his life. In 1834, his first wife, Mary Storer Potter died of a miscarriage in Rotterdam, when he journeyed in Europe as a preparation before he took the chair of the Smith Professorship of Modern Languages in Harvard College. "He was deeply saddened by her death, writing 'One thought occupies me night and day... She is dead—She is dead! All day I am weary and sad" (Note 1). Three years later, he was inspired to write the poem Footsteps of Angels about her. The other tragedy is the death of his second wife, Frances Appleton, the daughter of a wealthy Boston industrialist. Perhaps his seven-year Long courtship of Frances Appleton foreshadowed their unhappy ending. In 1861, their happy life came to an end. Longfellow's wife died of burns she received when the envelope of her children's locks and curls, which she was sealing with matches and wax, burst into flame and spread to her dress. Devastated by her death, he expressed his grief in the sonnet The Cross of Snow (1879), which he wrote eighteen years later to commemorate her death:

Such is the cross I wear upon my breast

These eighteen years, through all the changing scenes

And seasons, changeless since the day she died. (Note 2)

Longfellow faced the two bitterest tragedies of his life. However, he never succumbed to life and fate. He, the hero still continued striving in life. He undertook the task of translating Dante into English and wrote many lyrics, ballads, and epic poems, such as Voices of the Night; The Courtship of Miles Standish; Evangeline: A Tale of Acadie, The Song of Hiawatha etc. He was regarded as the first American to translate Dante Alighieri's The Divine Comedy. In his old age, he had received numerous honors. He was given honorary degrees at the great universities of Oxford and Cambridge, invited to Windsor by Queen Victoria, and called by request upon the Prince of Wales. He was also "the first American poet to achieve an international reputation" (Gioia, 2000:64), "the most popular living author in any genre in nineteenth-century America"(ibid) and enjoyed "a type of fame almost impossible to imagine by contemporary standards" (ibid). When he died in 1882, the first American bust of him was put in the Poet Corner of Westminster Abbey.

\subsection{The Literary Review on H.W. Longfellow}

Although Longfellow was the most popular living author in his time, he could never imagine his fame and glory would be not that shining after one century. Literary studies on him home and abroad are comparatively scarce.

In his country, "few recent books on American poetry and university presses (Gioia, 2000:68)" and even fewer "textbooks" (ibid: 70) in the USA "mention him except in passing; almost none discuss him at any length" (ibid: 68). The reasons for his diminishing popularity in modern times is that he is criticized and resisted by modernists for "his genres Longfellow favored - the ballad, idyll, pastoral romance, and moral fable" (ibid) and "his stylistic strengths his contemporaries praised — clarity, grace, musicality, masterful versification, and memorability" (ibid: 69).

In China, not many textbooks on American literature for English majors cite Longfellow except Wu Weiren's 1990 version History and Anthology of American Literature. If one quotes him, it only quotes some of his poems as examples to illustrate points of rhetoric and rhythm, such as The Arrow and the Song (Zhang Jinxia, 2008:8), The Tide Rises, the Tide Falls (ibid:32), A Psalm of Life (Chen Caiyi, 2008:206). He has become a marginal figure except as a historical one. 
Due to his too much familiarity, he and his works are usually marginalized in modern times, just as "his brother Samuel wrote, 'it has perhaps grown too familiar for us to read it as it was first read.' (Gioia, 2000:78)", a tiny minority of studies (Arvin, 1963) home and abroad have ever conducted about him in the twentieth and twenty-first centuries.

In China, although his $A$ Psalm of life is exceedingly familiar to Chinese readers as the first foreign poem to be translated to Chinese, there is no M.A. thesis and $\mathrm{PhD}$ dissertation about him apart from some scholarly papers in some journals and magazines. They can be categorized in the following respects.

Some papers are conducted under the feeling of sympathy as the defense for Longfellow's declining, such as Liu Zhijun's Longfellow: A Darling of the 19th Century and a Foundling of the 20th Century, in 2007 and On the Characteristic of Longfellow's Poetry, in 2006; Yang Yunfeng's Longfellow's Poetry and New Chinese Poetry, in 2008.

Some studies are mainly focused on Longfellow's specific poems by mainly analyzing the stylistic features and aesthetic value. For instance, more than 3 papers concentrate on A Psalm of Life---Deng Na \& Chen Xiaofeng's The Stylistic Analysis of A Psalm of Life, in 2009; Qin Chenghua \& Pan Jianxin's An Explanation of Longfellow's A Psalm and the Employment of Figure of Speeches in the Poem, in 2006; Li Guangyi's A Brief Analysis of Longfellow's A Psalm of Life in 2008; Lan Lan's The Conveying of Deep Structures in Poetic Translation---Taking Three Translation Versions of A Psalm of Life for Example, in 2009.

As regards The Rainy Day, and The Tide Rises, The Tide Falls, and My Lost Youth, the papers are made in the respects of stylistics and Longfellow's outlook on life. (Tan Wenwen, 2009; Guo Tiankui, 2005; Ma Zhiyan, 2006; Li Guangyi, 2008).

Some are mainly focused on the musicality and philosophy that Longfellow reflected in his poems, such as The Arrow and the Song by Luo Yanyan (2002).

In addition, Longfellow's epics Evangeline and Hiawatha which made him outstanding and famous overnight in the $19^{\text {th }}$ century decline in the modern times. "Nowhere [in the USA] can the decline of Longfellow's critical reputation be measured more clearly than in his representation in serious historical anthologies. (Gioia, 2000:69)" In China, with as many efforts as I can make as possible, only one paper (Yang Mei, 2009) is found to be done for the analysis of Hiawatha in the view of the American Indian culture and none about Evangeline.

Besides, one author (Tu Jing, 2002) has made the tentatively comparative research between Longfellow and some ancient Chinese poets, like Meng Haoran. In Tu's paper, he tries to compare and analyze several nature poems written by Henry W. Longfellow and Meng Haoran from the angle of aesthetics.

Among a minority of Longfellow's studies home and abroad, there has even scarcely been one made from the perspective of eco-criticism. Eco-criticism aims at exploring the relation between literature and natural environment to find out the ecological wisdom in literary works so as to awaken the ecological consciousness of the contemporaries. Henry Wadsworth Longfellow, a poet who was concerned much about nature, wrote about sundry nature poems. Through his nature poems, Longfellow shows the value of nature by evoking people's love and care for nature, and makes them reconsider the Man - Nature relationship so as to seek the ecological balance on earth, including that from within the human world. By reading Longfellow in the light of such eco-ethical ideas as nature loving, concern for nature, everything being equal, anti-anthropocentrism, anti-slavery and living a poetic life, it is not difficult to discover the legacy glittering with ecological wisdom in Longfellow's poetry. Such wisdom is highly connected with Longfellow's "environmental niche". Nowadays, with the increasing deterioration and decaying of the environment, the ecological wisdom implied in Longfellow's poetry is of tremendous significance and of high relevance, for Longfellow's ecological wisdom in his poetry may provide a spiritual blueprint for human beings to develop a low carbon economy of sustainable development, and live a poetic life by reconsidering the relationships between nature and human beings, between nature and human society, between nature and human spirit.

\subsection{A Theoretical Introduction of Eco-criticism}

Since the 1960s, the Earth, our Mother Nature, has seen devastating changes, and the ecosystem in a vicious circle has been suffering myriads of ecological disasters, natural or human, manufacturing pollution, global warming, expanding population, acid rain, deforestation, desertification, irregular earthquakes and eruption of volcanoes, ozone layer depletion, and melting of polar glaciers. The human beings dwelling on earth and all creatures at large thus have been in danger and under hazards as well. Due to the ecological crisis, human beings have come to realize the importance of Mother Nature, and draw attention to and take measures to put the earth under protection and care. However, this kind of protection and care is far from enough.

Thus, eco-criticism, as one of the literary criticisms, originated in the USA in the one article named Literature and 
Ecology: An Experiment in Ecocriticism created by American scholar William Rueckert in 1978. He advocated applying the concept of ecology into literary research (Glotfelty, Cheryll \& Haroltd Fromm, 1996:XIX). By definition, eco-criticism, projecting a vivid view of interdisciplinary study by its academic term, is a literary, cultural and artistic study under the circumstance of ecology. The application of ecology to the literary studies is of multiple significance. It is eco-poetics, by attempting to explore literary ecology or applying the concept of ecology to the literary readings, teaching, and writing. But actually, 16 years before him, Rachel Carson, an eco-litterateur, the forerunner of eco-criticism as well as a biologist studying fish and wild creatures published her work Silent Spring which was considered as "the beginning of modern environmentalism" (Chen Maolin, 2009:25), which contains lots of knowledge of ecology, biology, and environmental science.

Entering the 1990s and $20^{\text {th }}$ century, the development of eco-criticism and ecological literature has met its bloom. (Lan Renzhe, 2003:7) It almost has touched every field and aroused environmental awareness and concern. The ecological issues are related not only to environment, but also to politics, economy, society, and even ethics. The application of ecology, a concept in the realm of natural science, to literary criticism is the realization of the marriage of literature and natural science. Under this marriage of science and humanity comes out a new mode of literary criticism in ecology, which is one of the important features in eco-criticism. In the technology-governed age, eco-criticism proceeds from the concerns of nature, and the ecosystem, and stretches the literary criticism to the range of nature and the ecosystem, which inevitably requires the interactive communication between literature and ecology in natural science and voluntarily arouses an interdisciplinary conversation. In this case, eco-criticism can reach its apogee. Several theories combining and integrating disciplines of the humanities and natural sciences are the important sources for eco-criticism. Edward O. Wilson offers the explanation of all the social behaviors based on the biological aspects of his Theory of Sociobiology. According to the Gaea Theory of another biologist James Lovelock, the biosphere of the Earth, actively adjusts the environment, but not passively adapts itself to the environment. Therefore, the Earth has its own physiological course like an individual creature. (Liu Wenliang, 2008:147)

It is far from enough to dissolve the ecological crisis only based on natural science. It should also be participated in and guided by humanities. The mitigation or even phasing out of the ecological crisis requires unleashing the bondage of the narrow anthropocentrism and the deconstruction of traditional disciplines based on mechanism, dualism, and reductionism. Apart from the realization of transcendence between humanity and natural science, eco-criticism should also fulfill the transcendence among humanistic disciplines. The increasingly deteriorative environment boosts the increasing awareness of the protection of the ecosystem, as the concept of ecology has already infiltrated every field of humanities, such as literature, arts, culture, politics, economy, philosophy, ethics etc. Thus, the decaying of the ecosystem has become a common issue that the humanities must confront and deal with.

Literature, one discipline of social humanities and mirroring the relationship among nature, culture and human civilization in the perspective of literary criticism, also shoulders the burdens and responsibilities to tackle the ecological crisis, although the practice seems impractical, and yet it will definitely arouse the people's awareness of protecting the earth, our Mother Nature. Under this circumstance, the article tries to divide Longfellow's ecological wisdom into three realms, the natural world, human society and human spirit. The $3^{\text {rd }}, 4^{\text {th }}$, and $5^{\text {th }}$ parts will respectively probe into Longfellow's ecological wisdom on nature, human society, and human spirit in his nature poems and poems on slavery, as he is one of the American poets preferring to write such a theme. Longfellow is a poet who not only reflects the natural world, but also shows his concern for human society as well as human's spiritual realm. The reasons why the article prefers to probe into these three realms lie in the following two aspects. Firstly, It is because after the deep exploration of Longfellow's poems on nature and human society, it naturally comes into my mind that Longfellow's ecological wisdom on nature and human society reveals itself, and further the poet's deep love on nature and the concern for human society foster his meditation in mind about the balance between nature and human spirit, and between human society and human spirit, and the ecological solutions to ecological crisis. Secondly, it is due to the fact that eco-criticism is a literary school that studies the relationship and interaction between the physical world and human culture, with its features as interconnectedness, interdependence, and interaction. Therefore, the article probes into Longfellow's ecological wisdom on nature, human society and human spirit, which not only refer to the three respective realms, but also to indicate the interrelatedness, the interdependence, and interaction between the three fields. (Note 3)

And before the exploration of his ecological wisdom, it seems necessary to explore the origin of Longfellow's ecological ideas, which will be dealt with in the next part.

\section{The Origin of Longfellow's Ecological Ideas}

Like any other creatures, human beings are also living in and getting influenced by the "environmental niche". The 
term "niche", coined by Charles Elton in the late 1920s, refers to "the place a species occupies in the biotic community" (Chen Maolin, 2009:31) or the environmental structure and condition which can maintain the life of a species. (Lu Shuyuan,2000:204) and "tells us that every entity, whether human or nonhuman, plays its unique role in keeping the integrity, stability and beauty of an ecosphere, and therefore every entity possesses intrinsic worth." (Chen Maolin, 2009:31) More often than not eco-critics utilize the theory of "niche" to investigate the development of a litterateur or an artist. The niche to human beings is much more complicated than to any other creatures governed by temperature, moisture, food, light, space, time etc. As a litterateur, he or she should not only be affected by his material and political conditions, but also be influenced by his or her culture, custom, value, and spiritual surroundings. And the latter would affect him or her more than the former. In this part, the present article is going to probe into the origin of Longfellow's ecological ideas by sub-exploring the living environment of Longfellow's childhood, and the inerasable influence of American social upheaval in the middle of 19th century.

\subsection{The Living Environment of Longfellow's Childhood}

In the psychological sense, apart from genes, one's early experience in one's childhood exerts enormously significant effect on the formation of a person's personality and characteristics. "Some modern psychologists declare that too great emphasis has been laid upon heredity and environment, that each person is architect of his own character to a far greater degree than is commonly granted, and that many evolutions of later traits are wholly distinct from influences of birth or early training."([quoted by] Chen Maolin, 2009: 55) As for an artist or a writer, the early experience is more important, and can influence his or her thinking patterns, future writing styles, aesthetic appreciation etc. This early experience originates from his or her environment where an artist or a writer lives during his or her childhood. The stimulations from the surrounding environment, even the trivialities in his or her childhood, can cast eternal traces in the comparatively innocent, pure and harmonious mind and heart of a child. And then they will be turned into his or her memories, and further become more than precious treasures in his or her future literary and artistic creation, which echoes Lu Shuyuan's perception about the tremendously important role of the living environment of a child in the formation of a writer's world and life outlook. (Lu Shuyuan, 2000: 211)

Longfellow as a human being and great literary thinker could not escape from the niche surrounding him and he played its definite role and integrated with other creatures in that niche where he could be nurtured and inspired from. Most of the poems that Longfellow created cannot be disappointingly severed with Mother Nature he lived with, as he spent most of his lifetime in New England. He was indulged and intoxicated by the green woods, beautiful hills and clear water surrounding him, where his sparks of nature poems were ignited. Just as Charles C. Calhoun in 2004 described in the second chapter of his work Longfellow: A Rediscovered Life:

The original settlement of Portland had been strung across a three-mile-long peninsula. Longfellow grew up in the house his grandfather had built along the ridge of that peninsula, roughly halfway between its fortified eastern tip at Mountjoy's hill and steep, wooded Bramhall's Hill to the west. From the windows of the third story where Henry and his older brother Stephen and their maiden aunt Lucia had their chambers, you could look south and east to the wharf-lined Fore River and Casco Bay, and out beyond to Portland Head Light, Cape Elizabeth, and the cold Atlantic, to the north and west, across the mussel beds of the Back Cove, were the meadows of Gorham, home of many the Longfellows, and the distant hills that sheltered Hiram, where the Wadsworths had their farm. When the weather was clear in this land of frequent fog and damp, you could see Mount Washington, seventy miles away in the White Mountains of New Hampshire. The doubleness of this view- the running back and forth form one window to another to encompass it all-was to color the younger boy's poetry and his life. (Calhoun, 2004:5)

According to Charles, he also believes that the living condition in Longfellow's childhood cast a great influence on his future poem creation and his life.

\subsection{The Inerasable Influence of American Social Upheaval in the Middle 19th Century}

Longfellow lived in the $19^{\text {th }}$ century, ranging from the early to the late, where the USA underwent a tough time from an agricultural country to the industrial one. This special time led to the easy burst of every contradictory and triggering force. In the middle of the $19^{\text {th }}$ century, exactly from 1861 to 1865 , the USA saw the civil war between the North and the South on the issue of slavery. After the war, America developed at skyrocketing speed and saw the economic boom as well as faced fierce competition. In order to struggle to live, people tried everything they could. Behind the boom were large numbers of bloods, poverty, and misery. Capitalism brought about the financial crisis, the social upheavals, and the increasing unemployment. At the same time, the accomplishment of west movement had enlarged the gap between dream and reality. Nearly the whole society was under the dark cloud of frustration, disillusion, dissatisfaction, and resistance. The social ecosystem of the USA was in disconcerting unbalance, which inevitably would affect the spiritual ecology. That is why Longfellow turned to nature in his poems to mediate on and confess the wrong doings of human beings, destructing the anthropocentrism and show his attitude of 
anti-slavery. "Longfellow, from the beginning of his career, was vigorous in his condemnation not just of slavery but of racial inequality in general." (Irmscher, 2009: 109) Just as Longfellow calls on people in response to the call of nature in his poem Sunrise on the Hills:

If thou art worn and hard beset

With sorrows, that thou wouldst forget,

If thou wouldst read a lesson, that will keep

Thy heart from fainting and thy soul from sleep

Go to the woods and hills! No tears

Dim the sweet look that Nature wears.

According to Longfellow, if you fell weary, dreary, and sorrowful, and tired of the life in society, the woods which represent nature will embrace your heart from fainting, and your soul from sleep. Thus, you will get the sweetness from nature.

\section{Longfellow's Ecological Wisdom on Nature}

Of all the poems Longfellow composed opulently during his life, there were varieties of themes, such as nature, love, religion, life, death, and legend, almost all he has touched upon like such Romantic poets as Emily Dickinson, Walt Whitman, his contemporaries in his times. But it seems that the modern critics prefer the latter poets than the former, for they label him in Edgar Allen Poe's words "a determined imitator" (Note 4). It is axiomatically true that in Longfellow's poems especially his sonnets one can trace the influence of the English tradition. However, as the descent of the puritans escaping from the English persecution, he, with the heritage of the American culture and American spirit, was more concerned about freedom and individualism, and by far attracted by the expansive wilderness of the new continent. At the same time, during his European travels in Madrid, the young Longfellow was encouraged by Washington Irving, and was impressed and inspired by Irving's The Sketch Book (Note 5). And also, when he studied in Bowdoin College, he made friends with Nathaniel Hawthorne, and their ardent friendship lasted eternally in his life. All these American romantic elements would indisputably flow in his vein of works, just as quoted in Longfellow: A Rediscovered Life, (Calhoun, 2004) "Ah, he is a man of genius. There is great freshness, force and originality in that man [Longfellow], and his long life in the little provincial town has not tamed him, nor made him in any way common-place. (Calhoun, 2004:172)" Therefore, Henry Wadsworth Longfellow is more regarded as an American original poet in content than in form. Thus, it is the case with his nature poems. In this part, the present author is going to probe into Longfellow's ecological wisdom on nature in his nature poems where the ecological sparks can be traced.

\subsection{Concern for Nature and Love Nature}

Most of poems that Longfellow created cannot be disappointingly severed with the Mother Nature he lived with, as he spent most of his lifetime in New England. He was indulged and intoxicated by the green woods, beautiful hills and clear water surrounding him, where the ecological sparks in his nature poems were ignited.

In the nature poems of Longfellow, he shows us beautiful, lively, and lavish natural scenery. Voices of the Night can be taken for an elaborate example. In the beginning of the poem, the poet depicts a pleasant nature scene where there are green woods, soft winds, and the foliage grows luxuriously in the sylvan scene:

Beneath some patriartical tree

I lay upon the ground;

His hoary arms uplifted he,

And all the broad leaves over me

Clapped their little hands in glee,

With one continuous sound;-

and

The green threes whispered low and mild;

It was a sound of joy!

They were my playmates when a child,

and rocked me in their arms so wild! 
Still they looked at me and smiled,

As if I were a boy;

The poet turns back to a child in the eyes of Mother Nature and enjoys the beautiful scenery and serene security. This serene security brings him nice dreams:

Dreams that the soul of youth engage

Ere Fancy has been quelled;

Old legends of the monkish page,

Traditions of the saint and sage,

Tales that have the rime of age,

And chronicles of Eld.

In the console and comfort of nature he dips and contemplates on the legacy and traditions of saints and sages and old generations that nature nurtures and bequeaths. He then sings the praises of nature and eulogizes nature in the following lines:

And, loving still these quaint old themes,

Even in the city's throng

I feel the freshness of the streams,

That, crossed by shades and sunny gleams,

Water the green land of dreams.

The holy land of song.

Another example in the excerpt of the following Hymn to the Night, even shows Longfellow's explicit love towards nature. He extols the beauty of the night and personalizes it as a sleek girl wearing the "sable skirts all fringed with light".

$$
\begin{aligned}
& \text { I heard the trailing garments of the Night } \\
& \text { Sweep through her marble halls! } \\
& \text { I saw her sable skirts all fringed with light } \\
& \text { From the celestial walls! } \\
& \text { I felt her presence, by its spell of might, } \\
& \text { Stoop o'er me from above; } \\
& \text { The calm, majestic presence of the Night, } \\
& \text { As of the one I love. }
\end{aligned}
$$

From all the examples above, the poet's ardent love and mellow concerns towards nature are truly and musically revealed. Why does he love nature so much? In the words of his poem The Spirit of Poetry, he tells us:

\section{As a bright image of the light and beauty}

That dwell in nature.

Vehement love and concern towards nature is one of the ecological wisdom Henry Wadsworth Longfellow wants to convey in his nature poems. It is also one of the responsibilities that all citizens on earth should bear in mind and carry out in fighting against the ecological crisis and build an idyllic home where human beings can live comfortably.

\subsection{Everything Being Equal: Man as Part of Nature}

In ancient China, everything being equal has already been carved as an important and essential belief particularly in Taoism and Buddhism. Taoists manage to prove the equality in the perspective of the popularity of Taoism while the followers of Buddhism admit such equality proceeding from inner relations within Buddhism and the belief that everything and everyone can become Buddhist. (Ren Junhua, Liu Xiaohua, 2008:239)

To justify the idea of everything being equal more scientifically, the knowledge of biology and genetics are cited. Based on modern biology and genetics, it has been solidly proved that human beings and other creatures are all made up of basic cells, and share most genetic similarities and essences. They are born out of same roots and same 
mechanism. Theoretically speaking, human beings and any other creatures are all created equally and human beings have not any privilege or priority and are not superior to the latter. In the minds' eyes of ancient Chinese literati, the concept of everything being equal is not only restricted to creatures, but also in the whole universe at large. (ibid) The acceptance of the outlook of everything being equal requires us to show respect and love towards nature, and most importantly, to live harmoniously and peacefully with nature, and to open our vehement and congenial arms to embrace our mother nature, and admit that man is part of nature. To achieve this goal, human beings should treat everything not out of their own needs and benefits and meanwhile should not put everything of nature including human beings themselves in the conspicuous classification and hierarchy. Although Longfellow lived on the other side of the world far away from China in America, his ecological wisdom that can be traced in his poems on the concept of everything being equal: man as part of nature echoes that of Chinese philosophers. For example, in his poem Flowers, Longfellow extols stars shining in the earth's firmament. In the eyes of Longfellow, human beings can read our history from stars; meanwhile, the creation of human beings is evident in those stars of earth, and those golden flowers. He then points out:

And the poet, faithful and far-seeing,

Sees, alike in stars and flowers, a part

Of the self-same, universal being,

Which is throbbing in his brain and heart.

and

These in flowers and men are more than seeming

Workings are they of the self-same powers,

Which the poet, in no idle dreaming,

Seeth in himself and in the flowers.

Longfellow clearly announces from the bottom of his heart that human beings like any other entities are actually part of nature and they should coexist as a whole never to be separated in nature. They need to live peacefully and harmoniously. His belief echoes our ancient Chinese Confucius' philosophical concept that man is an integral part of nature.

\section{Longfellow's Ecological Wisdom on Human Society}

\subsection{Everyman Being Equal: Anti-Slavery}

In the previous section, the concept of everything being equal has been elaborated and its focus is on the relationship between man and nature, while this section is focused on the relationship between human beings, that is, everyman being equal. As is known, human beings and any other creatures are all created equally and human beings have not any privilege or priority and are not superior to the latter. Therefore, human beings should treat everything not out of their own needs and benefits and meanwhile should not put everything of nature including human beings themselves in the conspicuous classification and hierarchy. Thus, the idea of putting human beings in the social hierarchy is an inexactitude.

However, in the United States, the unfairness of putting human beings in the social hierarchy rests on the slavery system.

The first slaves arrived in Virginia around 1619, and slavery existed in America for the next 250 years. Africans made up the largest number of migrants to the New World during the colonial era, especially during the eighteenth century. During the four centuries of the Atlantic slave trade, an estimated 11 million Africans were transported to North and South America. In the United States, slaves had no rights. A slave could be bought and sold just like a cow or horse. Slaves had no say in where they lived or who they worked for. They had no representation in government. Slaves could not own property and were not allowed to learn or be taught how to read and write. Beginning in the $1750 \mathrm{~s}$, there was widespread sentiment that slavery was a social evil and should eventually be abolished, but even the Emancipation Proclamation of 1863 did not end slavery. Slavery continued in the states that were part of the Union forces. Slavery came to an end in 1865 when the 13th Amendment was ratified after the end of the Civil War." (Note 6)

In his poems of slavery, Longfellow advocates the socially ecological balance within human beings themselves in sublimating the concept of everyman being equal, echoing the Chinese scholar Lu Shuyuan's (2000:146-147) and Chen Maolin's (2009:1) idea of social ecology, as one of the three important levels to study ecology in the field of eco-criticism. The other two are natural ecology and spiritual ecology. Social ecology pays attention to the problems 
and conflicts within human beings. When human history enters a modern time, apart from the conflicts existing between human and nature, it also provokes equally serious problems between human beings themselves. It is the case of the slavery system in the USA in the Longfellow's time, even today still smoldering. The slavery system in essence is the hierarchical domination of the African Americans by the whites out of racial discrimination, and the deprivation of the Negro's human rights. To safeguard human freedom, Longfellow severely attacks the slavery system and his attitudes towards anti-slavery is mainly embodied in his 8 poems on slavery: To William E. Channing, The Slaves Dream, The Good Part that Shall not Be Taken Away, The Slavery in The Dismal Swamp, The Slave Singing at Midnight, The Witness, The Quadroon Girl and The Warning.

To William E. Channing is a poem Longfellow wrote in 1842 in testimony of his admiration for a great and good man when he heard of the death of Dr. Channing who was an abolitionist of slavery. As for The Slave's Dream, he eulogized the hardship, industriousness, and fortitudes of the slaves, and showed his sympathy for their hard and miserable life. He depicted a slavery dreamed a dream where he dreamed his journey back to his hometown in Africa and could have his freedom there, and "He did not feel the driver's whip,/ Nor the burning heat of day". How ironical it is!

In The Slavery in The Dismal Swamp, the poet compared the living situation of slaves to the dismal swamp:

Where will-o'-the-wisp and glow-worms shine,

In bulrush and in brake;

Where waving mosses shroud the pine,

And the cedar grows, and the poisonous vine

Is spotted like the snake;

Where hardly a human foot could pass,

Or a human heart would dare,

On the quaking turf of the green morass

He crouched in the rank and tangled grass,'

Like a wild beast in his lair.

The swamp is so dangerous and vile, even the human beings cannot pass. But who built this swamp? That is human beings themselves, more exactly the whites who think they are superior to the blacks. Who can save the slaves in this treacherous situation? Just as Longfellow, frustrated and sanguine, cried out in his poem The Slaves Singing at Midnight:

Paul and Silas, in their prison,

Sang of Christ, the Lord arisen,

And an earthquake's arm of might

Broke their dungeon-gates at night.

But, alas! What holy angel

Brings the Slave this glad evangel?

And what earthquake's arm of might

Breaks his dungeon-gates at night?

Paul and Silas in their prison can be saved by god when they pray, but can the slaves be equally saved when they pray too? In The Warning, Longfellow gave the whites a warning:

Beware! The Israelite of old, who tore

The lion in his path, - when, poor and blind,

He saw the blessed light of heaven no more,

Shorn of his noble strength and forced to grind

In prison, and at last led forth to be

A pander to Philistine revelry,- 
Upon the pillars of the temple laid

His desperate hands, and in its overthrow

Destroyed himself, and with him those who made

A cruel mockery of his sightless woe;

The poor, blind Slave, the scoff and jest of all,

Expired, and thousands perished in the fall!

There is a poor, blind Samson in this land,

Shorn of his strength and bound in bonds of steel,

Who may, in some grim revel, raise his hand,

And shake the pillars of this Commonweal,

Till the vast Temple of our liberties.

A shapeless mass of wreck and rubbish lies.

He satirically and ironically attacked the slavery system and hoped it could be abolished, and admonished that the whites and the blacks should live equally, peacefully and harmoniously, or the whites in the end would destroy themselves in its overthrow by laying their hands upon the pillars of the temple, or if the whites failed to change the situation, the slaves would "raise their hand and shake the pillars of this Commonweal".

\subsection{The Harmonious Development between Nature and Human Society: Anti-anthropocentrism}

As human beings suffer more ecological crisis nowadays than before, one may raise the questions," What is the root cause?" Is that because human beings use lots of chemical pesticides? Is that because we use biological and chemical weapons during wars? Those are not the root causes. The root cause lies in human beings' sense of superiority, more exactly anthropocentrism, which is fostered by human society. They believe, human beings are more granted rights by god and more superior to any other creatures, the belief of which can be traced back to the western biblical legend of how God created human beings. In the bible, God creates the world by creating the day and night first, then plants and animals, and last human beings. Most importantly and differently, it is well and widely believed God bestows on human beings great priorities and privileges to use and control any other creatures. The belief that the existence of any other creatures rests on serving human beings has since been imprinted and carved in human's minds. (Glotfelty, Cheryll \& Haroltd Fromm, 1996:9) Therefore, human beings proudly consider themselves as "the center" of the world. Lynn White, an eco-critic, has pointed out that Christianity not only establishes the dualism, separating human beings and nature, but also insists that the exploitation of nature is the will of God. (ibid:10) Driven by God's will, western countries have since put nature under control and exploitation out of the benefits and needs of human beings, just as William Rueckert has noted that the tragic flaw of human beings rests on the outlook of anthropocentrism, which guides human beings to conquer, tame, invade and exploit every entity of nature. (ibid:113)

When the history of human civilization wheels into the period of the Renaissance initiated in Europe, which advocates humanism, people enthusiastically cries out "Conquer Nature, Command nature, Control nature". The Three-C belief promotes and justifies human beings to continue exploiting nature with a sense of superiority. As human history moves into modern civilization, with the development of science and technology, people have ushered their unprecedented victory over nature. Victory? No. That is not a victory, for nature, black and blue, has revenged more bitterly on human beings.

It cannot be denounced and doubted that anthropocentrism has played its significant and remarkable role in the progress of human civilization, and yet it also brings human beings lots of detriments, and puts us under an ecological crisis. Nowadays, as the increasing threats to the existence of human beings that ecological crisis brings, the outlook of anthropocentrism has been challenged and criticized, and it also forces people to reconsider the relationship between human beings and nature. Lots of eco-critics (Glotfelty, 1996; Coup,2000; Wang Nuo, 2003; and Chen Maolin,2009) advocate and consider anti-anthropocentrism as one solution to alleviate or phase out the ecological crisis. Only by abandoning the doctrines of anthropocentrism can human beings survive the crisis and live peacefully and harmoniously on earth. As a new outlook, anti-anthropocentrism, the denouncement of anthropocentrism justifies the role of nature and regards human beings like any other creatures in nature as parts of the ecosystem on earth. Humans and nature are interrelated and interactive. That means how human beings treat nature is just the way they will be treated by nature. 
The perception of anti-anthropocentrism, another ecological wisdom of Longfellow is conspicuously shown in his poems where nature is awesome, august and incontrollable to him. For instance, in Woods in Winter, he depicts a doleful and awesome picture of the winter. The original lines run like this:

When winter winds are piercing chill,

And through the hawthorn blows the gale,

With solemn feet I tread the hill,

That overbrows the lonely vale.

The poet seemingly treads the hill solemnly, but in a hidden sense, he is nothing but a week entity in the eyes of nature. Human beings cannot control the piercing chill, cannot change the fate of the lonely vale, even he treads the hill solemnly. Then, he continues:

\section{Where, from their frozen urns, mute springs, \\ Pour out the river's gradual tide, \\ Shrilly the skater's iron rings, \\ And voices fill the woodland side.}

In this treacherous changing season, the mute springs come out from the vale like a frozen urn, and pour out the river's gradual tide. Human beings are helpless in front of it but like a skater skates on the ice echoing the scene of winter. Here, it seems Longfellow points out a path for human beings to eliminate the ecological crisis that human beings should adapt themselves flexibly to nature and become friends with nature, just as he concludes at the end of the poem:

\section{Chill airs and wintry winds! My ear \\ Has grown familiar with your song; \\ I hear it in the opening year, \\ I listen, and it cheers me long.}

If human beings cast off the skin of anthropocentrism in front of nature, nature will become friends and live harmoniously with them. It will fulfill the balance between nature and human society.

\section{Longfellow's Ecological Wisdom on Human Spirits}

In the previous parts, Longfellow's ecological wisdom on nature and human society has been elaborated respectively. In this part the focus of his ecological wisdom will be on his ecological wisdom on human spirits. According to Chen Maolin (2009), spiritual ecology is the key, for in order to realize the balance and harmony between nature and human society, it is imperative to firstly establish the spiritually ecological balance. Thus, the ecological wisdom on human spirits Longfellow reflected in his poetry is significantly relevant. Before unfolding the analysis of his ecological wisdom on human spirits in his poetry, it seems necessary to know what spirit is.

\subsection{A Brief Discussion of the Term Spirit}

Based on the definition that Oxford Advanced Learner's English-Chinese Dictionary (the $6^{\text {th }}$ Edition) provides, "spirit" refers to the part of a person that includes their mind, feelings and character rather than their body, and its plural form "spirits" denotes a person's feelings or state of mind. According to Dictionary of Philosophy, "spirit" is a concept broadly associated with concepts of the ideal, and of consciousness, the non-material entity, as distinguished from the material one; in the more restricted sense, synonymous with the concept of thought.

In addition, there are a lot of western scholars and experts, both ancient and modern, having attempted to define the term "spirit". For example, Aristotle believed that the highest activity of spirit was the thought about thought, while the American transcendentalist Ralph Waldo Emerson believed that spirit, "a most important entity in the universe in which nature stood as the symbol of spirit" (Note 7), is an oversoul different from material one, a kind of vigorous life-force, a precious and indispensable part of the communication between human and god. In modern times, Scheler, a German philosopher defined the term "spirit" as being unrestricted, free, and independent, and being a kind of energy of self-conscious, self-transcendence, and self-sublimaion. Having sorted out the different definitions, the Chinese professor, Lu Shuyuan (2000) proceeds that "spirit" is not only reason, consciousness, but also an actual metaphysical being in the Cosmos. It is the principle of nature, the intension of life, a state of mind characterized by the yearning for perfection, consummation, and harmony. ([quoted by] Chen Maolin, 2009: 153)

To sum it up, the definition that $\mathrm{Lu}$ Shuyuan gave cannot be more agreed with, because Longfellow also implicitly 
in his poems expressed his idea of spirit which is a conscious state of mind, related to nature, and an indispensable part of humanity featured by the pursuit of thought, wisdom, peacefulness and harmony among nature, human beings and human spirits.

\subsection{Spiritual Inspiration from Nature}

For Longfellow, our mother nature functions as nurturing the seeds of thought and wisdom in the mind and catalyzes it to blossom by watering carefully and tenderly. In the mind's eyes of Longfellow, nature is always offering people hints and inspiration, and people can benefit a lot from them and understand the hidden wisdom through careful observation and profound contemplation. For instance, in the poem The Light of Stars, Longfellow first described a cold, indifferent dark and silent night with little moon in the sky, and there was no light in earth or heaven except the cold light of stars. That was not the tender star of love or dreams, but the star of strength. In the celestial sky, only the resolute stars shone, which the poet saw them stand and smile upon his pain, and beckoned with their mailed hands from where, he gained his strength and unconquered will. Looking at the stars, he contemplated on life which sometimes is not always smooth, and then he came to an agreement with the resolution and calm and self-possession that stars revealed. In the end, he responded to the hints of nature and acclaimed:

And thou, too, whosoe'er thou art,

That readest this brief psalm,

As one by one thy hopes depart,

Be resolute and calm.

O fear not in a world like this,

And thou shalt know erelong,

Know how sublime a thing it is

To suffer and be strong.

From these lines, the poet seems to tell us the flower of success in blossom needs to be watered carefully by the juice of resolution and fortitude. Only in this way can the success last longer and longer. Or the road we are going to take will diminish ahead. So it is highly relevant to our situation nowadays where the eco-system is heavily damaged by greedy people who want to selfishly invade and control nature. If human beings want to eliminate the ecological crisis successfully, they need to resolve to abandon their way of life and outlook of anthropocentrism and to show their ardent enthusiasm and love towards nature.

Another poem Snow can be taken as another example to show how Longfellow gained its thought and wisdom from nature. The original lines go like this:

Out of the bosom of the air,

Out of the could-folds of her garments shaken,

Over the woodlands brown and bare,

Over the harvest-fields forsaken,

Silent, and soft, and slow

Descends the snow.

Even as our cloudy fancies take

Suddenly shape in some divine expression,

Even as the troubled heart doth make

In the white countenance confession,

The troubled sky reveals

The grief it feels.

This is the poem of the air,

Slowly in silent syllables recorded;

This is the secret of despair,

Long in its cloudy bosom hoarded,

Now whispered and revealed 
To wood and field.

Looking at the falling of snow which descends from the sky, out of the cloud, over the woodlands, and at last to the field, the poet thought of his late wife Frances Appleton in grief, and realized that the fate and life of human beings is just like those of snow, which symbolizes the birth, the growth, and the end of a life. It is the same with his marriage with Frances Appleton. His low spirit was ignited by the scene, and he felt that life is bitter, and helpless, but he regarded it in calmness, aplomb and self- possession.

\subsection{A Spiritual Home for Healing the Weary Heart and Soul: The Balance between Nature and Human Spirits}

In the eyes of the poet, nature not only functions as nurturing the seeds of thinking and wisdom in the mind but also as granting a spiritual place of pleasure, happiness to a weary mind. He would rather be intoxicated in nature rather than in the fatiguing and dreary city. Nature functions as healing and cleansing the weary minds and brains and his spirit and mind would recover in the embrace of nature. The following lines show the balance between nature and the poet's spirit:

Falling on my weary brain,

Like a fast-falling shower,

The dreams of youth came back again,

Low lispings of the summer rain,

Dropping on the ripened grain,

As once upon the flower.

In the eyes of nature, the poet feels that he is a child of nature and the dreams of his youth come back, despite the procession of adults or the crippling and stumbling of old age. In nature, he thinks that irrespective of ages, genders, and colors, everyone should be truly open to her, breathing her fresh air, sucking her honeydew of rain, and embracing ourselves with her. In this world of avoidance of hustling and bustling, people are pure, placid and peaceful, and nature is just the spiritual home for healing the weary heart and soul. Thus, the balance between nature and human spirit can be achieved.

\subsection{An Ecological Solution to the Ecological Crisis: Living a Poetic Life}

Living a poetical life is as well one of the ideas and goals of eco-criticism. Quoted from Chen Maolin in his work (2009), "Poetically Dwelling on Earth" originally appeared in the poem of the German poet named Friedrich Holderlin (1770-1843). The original lines go like this: "Full of merits, yet poetically, man/Dwells on this earth." Later, the expression "poetically man dwells" has become well-known through the interpretation and evaluation of Martin Heidegger (1889-1976), a famous German philosopher in the field of existentialism. It has three aspects of its connotation: preservation, freedom, and harmony. That means that "all the natural entities on earth including human beings exist together freely, peacefully, and harmoniously." (Chen Maolin, 2009:2)

Actually, nearly a century before Heidegger threw lights upon "poetically man dwells", Ralph Waldo Emerson (1803-1882) had already touched this idea implicitly in his masterpiece Nature in September 1836.

The charming landscape which I saw this morning, is indubitably made up of some twenty or thirty farms. Miller owns this field, Locke that, and Manning the woodland beyond. But none of them owns the landscape. There is a property in the horizon which no man has but he whose eye can integrate all the parts, that is, the poet. This is the best part of these men's farms, yet to this their warranty-deeds give no title. To speak truly, few adult persons can see nature. (Emerson, 1983:9)

According to Emerson, only the poets can own the whole nature and live peacefully and harmoniously on earth with any other creatures.

Henry Wadsworth Longfellow (1807-1882), lived in the same century as Emerson and it seems in his poems his ecological wisdom coincided with Emerson's. For example, in The Spirit of Poetry, he described like this:

...And here, amid

The silent majesty of these deep woods,

Its presence shall uplift thy thoughts from earth,

As to the sunshine and the pure, bright air

Their tops the green trees lift. Hence gifted bards

Have ever loved the calm and quiet shades. 
For them there was an eloquent voice in all

The sylvan pomp of woods, the golden sun,

The flowers, the leaves, the river on its way,

Blue skies, and silver clouds, and gentle winds,

The swelling upland, where the sidelong sun

Aslant the wooded slope, at evening, goes,

Groves, through whose broken roof the sky looks in,

Mountain, and shattered cliff, and sunny vale,

The distant lake, fountains, and mighty trees,

In many a lazy syllable, repeating

Their old poetic legends to the wind.

And this is the sweet spirit, that doth fill

The world;...

According to Longfellow, the poetic spirit lies on the serenity of nature, which fills the world, what a talented poet should do is indulged in the deep woods, golden sun, flowers, the leaves, the river, blues skies, silver clouds, and gentle winds which peacefully and harmoniously coexist and run based on the law of nature. From them, the bards' thoughts and wisdom would be lifted and they would play the old poetic legends musically to the world. The bard stands for human and the legend stands for the human society and the poets' thoughts represent the human spirit. They are all in balanced development. Only when the three realms work peacefully and harmoniously together, can human beings dwell on earth poetically, can human beings live a peaceful and harmonious life. This is the ecological solution that Longfellow advanced in his poem to fight against the ecological crisis.

\section{Conclusion}

Out of the worsening global ecological crisis, and under the influence of the upsurge of environmental preservation movements, studying the nature poems and poems on slavery of Henry Wadsworth Longfellow in the eco-critical aspect is highly and significantly relevant. Meanwhile, eco-criticism, a literary critical school sprouting early in the 1970s, and making its presence felt in literary circles in the 1990s, which is focused on ecological protection with ecological consciousness awakening as its central task, and on the study of the relationship between literature, culture, and environment, has also availed us of another way to study him.

Despite the fact that Henry Wadsworth Longfellow in a strict sense didn't really compose what eco-critics called "Ecological Writing", nor was he like the environmentalists calling on people to protect nature and the ecosystem directly, yet it will not be an impediment for us to read him in the perspective of eco-criticism.

Setting Longfellow in the framework of eco-criticism, this present article has explored his ecological wisdom in his nature poems and poems on slavery in the perspectives of his ecological wisdom on nature, his ecological wisdom on human society and his ecological wisdom on human spirits. As a common dweller on earth, he presents myriads of ecological and ethic illumination and thoughts in the light of nature in his poems and the social and spiritual balance between human beings themselves. Under the ecological wisdom on nature, it can be found that Longfellow is a nature lover, and show his concern for nature. Meanwhile, he puts the concept of everything being equal on an important level, and in his eyes, all creatures are equal on earth and man is an integral part of nature. Under the chapter of his ecological wisdom on human society, his further focus on everyman being equal and his attitude on anti-slavery. He, like his contemporaries Henry David Thoreau, Edgar Allen Poe, criticized the slavery system, and anthropocentrism. The doctrine of anti-slavery and anthropocentrism is not acceptable and agreeable. In the fifth chapter of his ecological wisdom on human spirits, he extols the spiritual inspiration from nature and considers nature an idyllic home for healing the weary heart and soul. Living a poetic life where human and any other entities coexist peacefully, equally, and harmoniously is his ecological solution to ecological crisis and also an important ecological wisdom.

In addition, the present article also probes into the origin of Longfellow's ecological ideas in the angles of the living environment of Longfellow's childhood, and the inerasable influence of American social upheaval in the Middle 19th Century.

Under the circumstance of the deterioration of ecosystem, the attempt to study Longfellow's ecological wisdom is highly relevant, and Longfellow's ecological wisdom comes to remind us of respecting, protecting and caring for 
nature and his ecological wisdom will provide a spiritual blueprint for human beings to develop a low carbon economy of sustainable development, and live a poetic life by reconsidering the relationships between nature and human beings, between nature and society, between nature and human spirit. Only in the pursuit of harmonious coexistence between nature and human, and the peaceful and symbiotic development of nature and culture, and the balance between nature and human spirit, can the ecosystem operate in the virtuous circle and can human beings live a congenial life and poetically dwell on earth.

\section{References}

Arvin, Newton. (1963). Longfellow: His Life and Art. Boston: Atlantic Monthly.

Calhoun, Charles C. (2004). Longfellow: A Rediscovered Life. Boston: Beacon Press.

Chen Caiyi. (2008). The Rhythm and Types of English Poetry. Chengdu, Sichuan: Sichuan People Publishing House. Chen Maolin. (2009). Poetic Dwelling: An Ecocritical Study of Henry David Thoreau. Zhejiang: Zhejiang University Press.

Coupe, Laurence. (ed.). (2000). The Green Studies Reader: from Romanticism to Ecocriticism. New York: Routledge.

Deng Na, Chen Xiaofeng. (2009). The Stylistic Analysis of A Psalm of Life. Journal of Chifeng College, 30(8), 93-94.

Emerson, Ralph Waldo. (1983). Essays \& Lectures. NY: Penguin Putnam Inc.

Glotfelty, Cheryll, \& Haroltd Fromm. (eds.). (1996). The Ecocriticism Reader: Landmarks in Literary Ecology. Athens \& London: The University of Georgia Press.

Gioia, Dana. (2000). Longfellow in the Aftermath of Modernism. In Parini, Jay \& Miller, Brett C (eds), The Columbia History of American Poetry. Beijing: Foreign Language Teaching and Research Press.

Guo Tiankui. (2005). A Brilliant Living, A Peaceful Dying: The Analysis of Longfellow's A Psalm of Life and The Tide Rises, The Tide Falls. Journal of Peiling Normal University, 21(4), 81-83.

Irmscher, Christoph. (2009). Public Poet, Private Man: Henry Wadsworth Longfellow. Boston: University of Massachusetts Press.

Lan Lan. (2009). The Conveying of Deep Structures in Poetic Translation-Taking Three Translation Versions of A Psalm of Life for Example. Journal of Guangxi University, 31, 313-314.

Lan Renzhe. (2003). Romanticism, Nature and Ecocriticism. Journal of Sichuan International Studies University, 19(5), 3-8.

Li Guangyi. (2008). A Brief Analysis of Longfellow's A Psalm of Life. Science Educator, 7, 211-212.

Li Guangyi. (2008). A Brief Analysis of Longfellow's My Lost Youth. Education for Chinese After-school(Theory), 701-702.

Liu Wenliang. (2008). Ecocriticism from the Perspective of Cultural Poetics. Social Sciences in Yunnan, 4, 145-148.

Liu Zhijun. (2007). Longfellow: A Darling of the 19th Century and a Foundling of the 20th Century. Journal of $X i$ 'an University of Arts and Science, 10(2), 20-22.

Liu Zhijun. (2006). On the Characteristic of Longfellow's Poetry. Journal of Xi'an University of Arts and Science, 9(3), 16-19.

Lu Shuyuan. (2000). Ecological Literature and Art Studies. Xi'an: Shaanxi People's Education Press.

Lu Shuyuan. (2000). Ecological Literature and Art Studies. Xi'an: Shaanxi People's Education Press.

Luo Yanyan. (2002). An Arrow Soaring in the Sky, A Song Rippling in the Heart: The Arrow and the Song. Journal of Fuyang Normal University, 3, 45-46.

Ma Zhiyan. (2006). Calmness and Peace in Sadness: An Analysis of the art of Language in The Tide Rises, The Tide Falls. Social Sciences Review, 21(2), 154-155.

Qin Chenghua, \& Pan Jianxin. (2006). An Explanation of Longfellow's A Psalm and the Employment of Figure of Speeches in the Poem. Journal of Qinzhou College, 21(5), 34-36.

Ren Junhua, \& Liu Xiaohua. (2004). The Cultural Interpretation of Environmental Ethnics-An Analysis of Ancient Chinese Ecological Wisdom. Changsha: Hunan Normal University Press.

Tan Wenwen. (2009). An Analysis of Longfellow's The Rainy Day from the perspective of Stylistics. Journal of 
Yibing College, 5, 28-29.

Tu Jing. (2002). A Comparison and Analysis of Nature Poems by Longfellow and Meng Haoran. Journal of Hunan medical university, 4(1), 15-19.

Wang Nuo. (2003). European and American Ecological Literature. Beijing: Peking University Press.

Yang Mei. (2009). A Man Singing for American Indians: An Analysis of Longfellow's Hiawatha. Journal of Changii University, 69-71.

Yang Yunfeng. (2008). A Study of The Influence of Longfellow's Poems on Chinese New Poems. Journal of Jixi University, 8(4), 80-81.

Zhang Jinxia. (2008). An introduction to English Poetry. Hebei: Heibei University Press.

\section{Notes}

Note 1. This is quoted from an article from wikipedia with its title named. Henry Wadsworth Longfellow.[Online] Available:http://en.wikipedia.org/wiki/Henry_Wadsworth_Longfellow (5 September 2011)

Note 2. ibid.

Note 3. Chen Maolin, an associate professor from Hangzhou Normal University and Lu Shuyuan, a professor from Suzhou University, as well as a leading scholar in the field of ecological research in literature and art in China, divide the ecosphere into the three realms: natural ecology, social ecology, and spiritual ecology. For details, see their respective works: Poetic Dwelling: An Ecocritical Study of Henry David Thoreau. (Zhejiang: Zhejiang University Press. 2009) P 1 and Ecological Research in Literature and Art (Xi'an: Shaanxi People's Publishing House,2000) P146.

Note 4. This is quoted from an article from a website with its title named. Henry Wadsworth Longfellow. [Online] Available: http://www.answers.com/topic/henry-wadsworth-longfellow. (8 September 2011)

Note 5. Ibid.

Note 6. This is quoted from an article from a website with its title named Slavery in America. [Online] Available: http://www.uen.org/themepark/liberty/slavery.shtml (26 October 2011)

Note 7. This is quoted from an article from a website with its title named Transcendentalism. [Online] Available: http://jpk.sicnu.edu.cn/viewdoc.asp?cno=20090102\&id=59 (30 October 2011)

*All the poems quoted in this article are from The Complete Poetic Works of Henry Wadsworth Longfellow by Longfellow, Henry Wadsworth. (1899). Boston and New York: Houghton Mifflin. 